\title{
Concert on the Island (Koncert na ostrově)
}

\author{
Author: Jaroslav Seifert
}

First Published: 1965

Translations: Slovenian (Koncert na otoku in: Jaroslav Seifert: Nobelova nagrada za literaturo 1984, 1985); Polish (Koncert na wyspie in Poezje wybrane, 1986; in part in Być poeta, 1997, in part in Księga pocatunków, 2019); Russian (in part in Proščanie s vesnoj, 1987); Slovak (Koncert na ostrove, 1988); English (in part in The Poetry of Jaroslav Seifert, 1998).

About the Author: Jaroslav Seifert (1901-1986) was a member of left-wing oriented artistic circles in between the world wars. He also worked as a journalist for many years. In the 1950s and 1960s, he supported his colleagues who were imprisoned authors, and he openly backed the liberalisation of Czechoslovakian cultural life. In 1969, he became the chairman of the Czech Writer's Union, but this was soon dissolved by the new generation of ruling Communist authorities. In some periods of the Communist regime, publication of his works was officially limited, so his texts were also printed abroad or in samizdat. In 1977, Seifert signed the human rights manifesto Charter 77. Besides writing poetry, he worked as a translator also in cooperation with other particularly educated professionals; e.g. The Song of Songs with Stanislav Segert (Píseñ písni; 1958, revised 1964). As a famous Czech poet, he wrote a book of his memoirs All the Beauties of the World, which was, after some changes, also allowed to be accepted by an official publishing house in 1982. He became the only Czechoslovakian holder of the Nobel Prize for Literature in 1984.

Further Important Publications: Deštník $z$ Picadilly (samizdat 1978; the official edition 1979; An Umbrella from Piccadilly, poems); Všecky krásy světa (samizdat 1979, the official censored edition 1982; All the Beauties of the World, memoirs).

\section{Content and Interpretation}

Seifert's Concert on the Island represents a turning point in his writing in regards to both theme and form, which changed radically. He abandons rich metaphorical language and regular harmonic verse with sophisticated rhyme structure and starts to prefer free verse, prose-like language and metaphorical austerity (Janoušek, 2008, p. 185; Zelinský, 1999, p. 339). In this collection of poems, he depicts a picture of Prague, strong subjectiveness and intimacy are still present as in the author's previous works. Nevertheless, the prevailing grim reminiscent perspective of World War II, motifs of danger and death, with only hints of hope begin to appear in Seifert's poetry.

Above all, this work - divided into eleven parts (songs) - is a kind of a "personal encyclopaedia of death. In such an eschatological concert even the figure of the lyrical 
subject is placed somewhere on the edge of life and death” (Balík, 2017, p. 36). Both Karel Kostroun and later Zdeněk Pešat have stressed the fact of the fleetingness of human life (lidská dočasnost) work (Kostroun, 1966, pp. 145-146; Pešat, 1991, p. 191; Balík, 2017, p. 36).

According to A. M. Píša, Jewishness is represented either by general visionary lament or "agonisingly incarnated in the particular creature of a girl called Hendele" (Píša, 1966, p. 267). The theme of the Shoah culminates in the eighth part of the collection called Through the Ropes of Nooses (Šňurami oprátek). The Holocaust is demonstrated in the poem The Song about Hendele, by a nursery rhyme, and the dry gnomic commentary added to the end of it. The evocative verses below reveal not only the tragic fate of the girl, but also a picture of the traumatised postwar mind of the lyrical subject (Balík, Holý, 2016, p. 492; Balík, 2017, pp. 36-37).

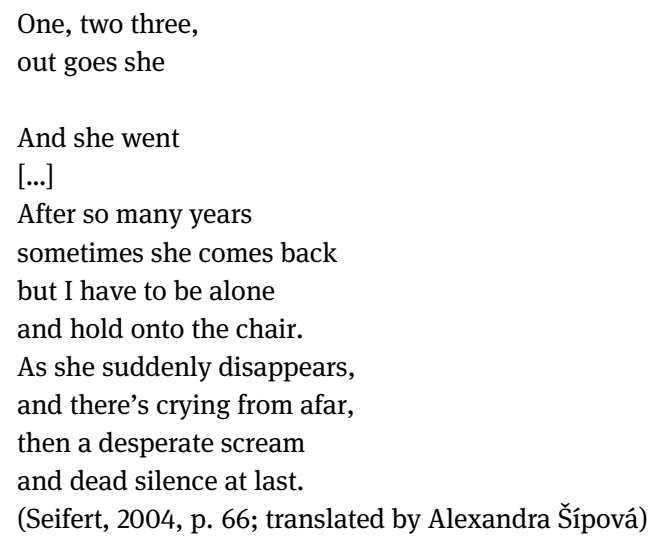

Thus, not only victims are displayed, but also the bystanders and Nazi oppressors. They are depicted by name, but also often implicitly or in general as in the case of Jews. The victims and simultaneously heroes are Jews as well as brave members of artistic circles (e.g. prose writer and playwright Vladislav Vančura and others) and the Czechoslovakian paratroopers, who assassinated Reinhard Heydrich, deputy Reichsprotektor of Bohemia and Moravia, and one of the authors of Final Solution to the Jewish Question.

In the 1950s, when Pinkas' Synagogue in Prague was renovated, the inner walls were used to commemorate the Jewish Shoah victims from the Czech lands. All of their names were written into the fresh façade of the walls. Seifert contrasts this list to the biblical Song of Songs as "the saddest song of all songs, / written on a moist wall recently” (Seifert, 2004, p. 68; Balík, Holý, 2016, p. 492-493). See Jiří Weil’s $\rightarrow$ Elegy for 77,297 Victims.

The picture of free and innocent plants as a hidden parallel to Czech bystanders appears repeatedly in contrast with imprisoned people (the Jews). This is similar to some of Michal Flach's poems in his book Looking Back from a Great Distance (1997). 
In Seifert's poem Just Be Calm, Everything Evil... (incipit), pansies in Theresienstadt fortress, whose surprised eyes look at the boots - metonymy of oppressors - are firstly blamed (damned pansies) and then they are excused (poor pansies) (Seifert, 2004, p. 73). The second short poem The Little Hendele Knows It Well (incipit) is written from a quasi naive childlike perspective, where barbed wire, the symbol of concentration camps, is compared to lines in a notebook. Meanwhile dandelions are in bloom pretending nothing has happened (p. 76). Above all, the lyrical subject counts himself among the bystanders in (I Feel Shame I Have Survived, p. 77) - in contrast with Vladislav Vančura who was executed during the war.

The Nazi oppressors are represented in various forms of "inadequate" shocking metonymies or periphrastic euphemisms implicitly. The assassinated Reinhardt Heydrich (p. 74) is mentioned as an alien corpse, which was driven away with flambeau at night. Members of the Nazi secret police Gestapo are depicted as „door-to-door sellers offering death“ (p. 77). In addition, the more drastic picture of objects made out of human bodies, which already have appeared in Jiří Kolář Eyewitness (Očitý svědek, 1949) as well as $\rightarrow$ The Liver of Prometheus and in Zofia Nałkowska's $\rightarrow$ Medallions, is presented - "Even their boots are made out of human skin" (p. 74).

\section{Main Topics and Problems}

As a result of Seifert's radically changed style, critics of the time (Brabec, 1966; Kostroun, 1966; Píša, 1966) and the literary historians (Pešat, 1991, pp. 190, 195-196; Zelinský, 1999, p. 339) concentrate on the sudden change of Seifert's poetic language and the theme of the Shoah stands out in their reviews of his later works.

A very similar reaction also happened twenty years before. The Czech poet with a Zionist orientation František Gottlieb (1903-1974), who served as a soldier of the Czechoslovak foreign army in Great Britain, released his collection of poems Double Line-Up (Dvojí nástup) in London in 1942. Despite the fact that A. M. Píša reflected on Jewish motifs, he concentrated on the different issues of Gottlieb's poetry, e.g. its formal registry (Balík, 2017, pp. 35-36).

On the other hand, in the context of Seifert's work after 1945, Josef Škvorecký, a Czech prose writer who became a part of Czech exile literature in the United States and Canada after 1968, mentioned his poem The Song of Hendele, written in memory of a girl who died in Auschwitz among Seifert's "lyrical slaps in the face of Nazism" (Škvorecký, 1985, pp. 289-290). Moreover, Škvorecký underlined that Seifert's poetry is untranslatable because of historical hints and coded meanings. It is not enough to only know all of them, but a reader should also be moved by them in a way that is simply not possible unless the person is Czech (p. 289).

Seifert's poetry in the context of the Shoah ought to be seen in the perspective of Polish (Milosz's $\rightarrow$ Selected Poetry) and Czech ( Kolář's The Liver of Prometheus, Radek Malý's $\rightarrow$ Crow Songs ) "bystanders writing”, which is very sympathetic in relation to the Jewish neighbours' fate and simultaneously regretting having taken no action to lead to their rescue. An explicit declaration of collective guilt of the Czech bystanders, 
who ought to also be responsible for their Jewish neighbours, appeared later in Seifert's poem Lost Paradise (Ztracený ráj) in the collection of poems Umbrella from Piccadilly in the late 1970s (Seifert, 2003, pp. 215-216; cf. Balík - Holý, 2016, pp. 494495), which was translated into English.

In the context of Czech poetry about the Shoah, Kolář can be considered a possible predecessor to Seifert with his prose-like poetry which uses free verse $\rightarrow$ The Liver of Prometheus (Balik, 2016, p. 143). However, Seifert developed his new specific free verse using e.g. surprising simile and gnomic style with sharp points (Janoušek, 2008, p. 185). Concert on the Island is considered the first step towards the de-poetising of his verses. He also cultivated the theme of the fight between evil and good in his later collections (Zelinský, 1999, p. 339). The thematic aspect thus matches the formal one - expressed in the words of the poet himself: "Away with the poetic junk / full of metaphors and rhymes / Life is freezingly bare sometimes” (Seifert, 2004, p. 78; Balík, Holý, 2016, p. 491).

\section{Cited Works}

Balík, Š. (2016). Czech Bystanders Writing Poetry about the Shoah: Different Ways of Poetic Languages in the First Post-War Literary Reactions. In: R. Ibler, ed., The Holocaust in the Central European Literatures and Cultures: Problems of Poetization and Aestheticization. Stuttgart: ibidem-Verlag, pp. 129-144. Balík, Š. (2017). Yelling into the Silence and its Echos: Czech Shoah Poetry Written till 1960s and its Reception. Poznańskie Studia Slawistyczne, (12), pp. 29-45. Balík, Š., Holý, J. (2016). Mezi tichem a křikem: Poezie o šoa. In: J. Holý, ed., Cizí i blizcí. Židé, literatura, kultura v českých zemích ve 20. století. Praha: Akropolis, pp. 431-520. Brabec, J. (1966). A zaklínám svou noc, která se přibližuje. Literární noviny, 15(5), p. 5. Janoušek, P. (ed). (2008). Dějiny české literatury 1945-1989. III. 1958-1969. Praha: Academia, pp. 184-187. Kostroun, K. (1966). Znamení básníka. Plamen, (2), pp. 145-146. Pešat, Z. (1991). Jaroslav Seifert. Praha: Československý spisovatel. Píša, A. M. (1966). Básnický čin. Impuls, 1(4), pp. 266-270. Seifert, J. (2003). Morový sloup. Deštník z Piccadilly. Býti básníkem. Dodatky. Ed. M. Jirásková. Praha: Akropolis. Seifert, J. (2004) Koncert na ostrově. Halleyova kometa. Odlévání zvonů. Dodatky (1966-1970). Ed. J. Flaišman. Praha: Akropolis. Škvorecký, J. (1985). Jaroslav Seifert - the Good Old Drinking Poet. Cross Currents, 4, pp. 283-290. Zelinský, M. (1999). Jaroslav Seifert. In: S. Serafin, ed., Twentieth-Century Eastern European Writers: First Series. Detroit et al.: The Gale Group, pp. 335-340.

\section{Further References}

Hájek, I. (1983). The Late Seifert. London Magazine, 23(8), November, pp. 53-57. 